\title{
Critical Analysis on TOEFL ITP as A Language Assessment
}

\author{
Wahyu Taufiq \\ Fakultas Keguruan dan Ilmu Pendidikan \\ Universitas Muhammadiyah Sidoarjo \\ Jl. Mojopahit 666B Sidoarjo \\ taufiq@umsida.ac.id
}

\author{
Dian Rahma Santoso \\ Fakultas Keguruan dan Ilmu Pendidikan \\ Universitas Muhammadiyah Sidoarjo \\ Jl. Mojopahit 666B Sidoarjo \\ dianrahma24@umsida.ac.id
}

\author{
Niko Fediyanto \\ Fakultas Ekonomi dan Bisnis \\ Universitas Muhammadiyah Sidoarjo \\ Jl. Mojopahit 666B Sidoarjo \\ fediyantoniko@gmail.com
}

\begin{abstract}
The evaluation of the use of TOEFL as a language assessment is the main concern to be studied on this paper. Using qualitative method, the researchers evaluate some specific questions mainly derived from a set of criteria which are practicality, test reliability, validity, authenticity and washback effect. The results concludes that the TEOFL ITP is practical and reliable. Its reliability lies to all three sections in this TOEFL. It is still noted however, that the TOEFL ITP may also be reliable as it is in TOEFL PBT unless the fact that the ITP test is adapted from previously used TOEFL. Theoretically, the reliability is doubted and further researches are still needed. In relation to the use of TOEFL ITP for a placement test, it is necessary to ask whether the test items can represent this task. The TOEFL ITP is approximately authentic as an English test. Understanding the impact of the TOEFL, test takers are inspired to study English more, as one of the washback of the test. More students want to get the lessons to raise their score to be higher.
\end{abstract}

Keywords-Toefl, assessment, ITP, English

\section{INTRODUCTION}

The Test of English as a Foreign Language or simply called TOEFL is one of current formal examinations which are broadly recognized. The test itself is a registered trademark of Educational Testing Service - ETS [3], which is located in United States. Mainly, there are two types of TOEFL, internetBased Test TOEFL (TOEFL iBT) and Paper-Based test TOEFL (TOEFL PBT). Both TOEFL are called the new generation TOEFL, which replace the older version of TOEFL tests [5].

The TOEFL iBT, as its name, is conducted via internet to replace the previous Computer Based TOEFL (TOEFL CBT). Since 2005, this test offers four skills being tested; Reading, Writing, Listening and Speaking. The TOEFL PBT, on the other hand, is also introduced to replace the previous TOEFL which is conducted using papers-based test. The difference between the previous version of paper-based TOEFL and the
TOEFL PBT is that the earlier version only tests three skills area; they are Listening, Structure and Written Expression, and Reading Comprehension. In the TOEFL PBT, offers the same test like the previous version of paper-based TOEFL with additional test of skill named Writing section. It is also noted, that this TOEFL is only conducted when the Internetbased test (TOEFL iBT) is not available.

In spite of those two generally-known TOEFL, ETS also releases other variations of TOEFL such as TOEFL junior for kids, and a more affordable English Proficiency test called TOEFL ITP, which stands for Test of English as a Foreign Language, Institutional Testing Program. This last name of TOEFL will be further explained and evaluated on this paper, particularly on its specific use as a placement test.

The TOEFL ITP is offered locally with a lot more affordable price. The fact is this kind of TOEFL becomes more popular and widely tested. The test forms like the genuine TOEFL PBT with only three sections being tested; Listening, Structure and Written Expression, and Reading Comprehension. It is administrated with a less secure environment using previously administered TOEFL Englishlanguage tests. Every year, more than 500,000 ITP tests are conducted worldwide and the number still continues to rise.

This type of TOEFL is utilized by many different institutions with variety of purposes. In Indonesia particularly, TOEFL has been long to be strongly believed as one of musttake tests to get a scholarship or to continue education and the TOEFL ITP was what mostly used. Even until now, some well-known scholarships providers for Indonesian people such as Fulbright, Australian Development Scholarships and Japanese Government Monbukagakusho scholarships Foundation still use and accept TOEFL ITP scores to get the applicant's English report as part of the further placement tests to win the scholarships. 


\section{TOEFL FOR ASSESSMENT}

Some of universities in Asia particularly, also conduct TOEFL ITP as a test of English as Foreign Language to enrol the institutions. One of them is Mahidol University International College, Salaya, in Thailand. Certain score of TOEFL ITP must be gained in order to let students enrol the institution along with other requirements [6].

In one of institutions in Malang, TOEFL ITP is conducted two times each year for different purposes. The first test is conducted as a part of placement test for new students to be allocated into certain level in a English language program conducted in the University. The second test is conducted conducted to assess the students' English ability for the last time, before they graduate to get a bachelor or master degree.

For those formal institutions, TOEFL ITP is chosen because of several reasons. Some of them are mainly because of the affordable cost, and the reputation of TOEFL which is believed to be reliable and valid. The researchers therefore believe that critical evaluation of TOEFL ITP test is important to be conducted, since there are many criteria of assessment that need to be clarified particularly on its use as a placement test.

To conduct the evaluation, the researchers arouse some specific questions mainly derived from the set of criteria mentioned by Brown [8] which are practicality, test reliability, validity, authenticity and wachback effect.

1. Are the TOEFL ITP test procedures practical to be used as a placement test?

ETS has been long conducting TOEFL tests and made sure that they are practical [1]. Overall, as the test is mostly adopted from the genuine TOEFL, the TOEFL ITP is practical to be conducted for any purposes. Not quite different for the other purposes, TOEFL ITP for a placement test particularly has been clarified that the details of administration are established in advance; along with the practicality to conduct the test without procedural problems as well as all materials and equipment. As it is framed in TOEFL ITP, three sections are separated along with the time needed and the students are mostly able to complete each section with the time allocated. Further, the cost of the test is the main attractive point why the test is chosen, since it is affordable within the budgeted limits. Also, with computerised scoring, the test evaluation system becomes feasible to do, along with the methods for reporting results that are determined in advance.

\section{Is the TOEFL ITP test reliable for a placement test?}

In 1997, Wainer and Lukhele reported that the TOEFL scores were perfectly reliable [9]. Even the reliability of the TOEFL score mentioned was the old version of paper-based TOEFL, the form exactly looks like TOEFL ITP now. The reliability lies to all three sections in this TOEFL, Listening, Structure and Written Expression, and Reading Comprehension.

Understanding the fact that the TOEFL ITP is derived from the paper-based TOEFL, it is still possible that the reliability may also be there. However, further critical evaluation is still questioned in the place or institutions that conduct the test. Different with the TOEFL iBT or TOEFL PBT, the TOEFL ITP is conducted onsite by every partner academic institution and then simply returned to ETS only for scoring.

It might be possible that every TOEFL ITP provider offers slightly different situation and facilities. One example can be focused from the number of participants. Since the number of TOEFL ITP test takers is not limited, their number can be a few with a small room being used, or on the contrary can be also a lot more, such as when a placement test with almost 100 participants is conducted in a larger room. As the consequence, the test takers from different institutions may receive different quality of the sound in Listening section. As a matter of fact, ETS has already advised the standard room, along with other supporting facilities being used, as long as the institutions conducting the test follow this, it is believed that the reliability of TOEFL ITP remains there [3].

It is still noted however, that the TOEFL ITP may also be reliable as it is in TOEFL PBT unless the fact that the ITP test is taken from previously tested TOEFL. Theoretically, the reliability should be doubted and further researches are still needed.

3. Is the test valid in measuring the level of English Proficiency?

For a test to be valid, it must meet several validity criteria, whether it is face validity or content validity. In relation to the use of TOEFL ITP for a placement test, it is necessary to ask whether the test items can represent this task.

The nature of all TOEFL tests is only for measuring the English proficiency, not judging whether someone is fail or pass. The TOEFL in general is only away to estimate the test taker's level of proficiency in English as a second language skill for academic purposes using a range of scores, such as Elementary which represent score 310 up to 420 , or the advanced user, which sores 525 up to 677 .

Kerans, et al. considered the TOEFL ITP to be valid in their part of research [4]. However, there are some facts about TOEFL ITP that influence its validity. The First weakness of this test is in satisfying the "English proficiency" itself. It is known, that there are only three sections being tested; Listening, Structure, and Reading Comprehension in TOEFL ITP. The speaking and writing tests are only available in TOEFL iBT version. The Speaking section is designed for teaching assistant screening and measures the general speaking proficiency construct [2] while the Writing section is also designed for computerized scoring which makes the language instructors easy to grade in a fair and exact way. Through practice on the computer, the test takers may improve their writing performance [1].

So analytically, the English proficiency being tested in TOEFL ITP is only on passive English. A person who has better proficiency in speaking or writing might not be able to show his capabilities here. Additionally, Templer argues that TOEFL ITP is only valid for the institution conducting the test [8]. This argument is mainly based on the fact that the test is conducted locally. Every institution is allowed to have the 
TOEFL ITP test, which the items in test are mainly taken from the genuine test that has been done previously.

Related to a placement test, it can be concluded that TOEFL ITP is valid for the every institution to conduct a placement test. However, it only tests several skills in English. Therefore, as advised by Roemer, more tests need to be conducted independently to accompany the result of the test, to have a alternative test particularly to test the Speaking and Writing abilities [5]. Also, for the bigger institutions such as international scholarships providers that use TOEFL ITP as an English requirement proves, they need to conduct their own test to clarify the result of the score [5].

4. Are the test tasks authentic to be used as a placement test?

The TOEFL ITP is approximately authentic as an English test. The authenticity can be estimated form the fact that the language in the test is natural and contextual. Even using multiple-choice tests, some thematic organization is provided as well as the tests represent approximate real-world tasks.

Related to a placement test in academic institutions, the TOEFL ITP is relatively authentic since it is a test of English proficiency in particularly English as a second language skill for academic purposes [5]. Still, as it is in line with what have been mentioned above, more tests need to be there to support the authenticity of the test.

5. Does the test offer beneficial washback to the test takers?

Understanding the huge impact of the TOEFL, particularly TOEFL ITP, test takers are inspired to study the English more, as one of the washback of the test. More students want to get the lessons to raise their score to be higher.

In order to be accepted by the university or passing a certain level in English language, students particularly as test takers are stimulated to concern with their TOEFL score by to studying more or even having a specific course for it. TOEFL in general has influenced a substantial impact to their washback. It has been found that TOEFL as a standardised test has promoted to the existence of the proliferation of private courses and schools, a authentic supermarket of testing materials and an expanding array of program designed to train teachers or instructors [8]. These circumstances are emerges based on the test takers' need to get a higher level in TOEFL score. The courses, materials as well as the tutors are prepared based on the kind of TOEFL itself [8]. For TOEFL ITP for instance, there are specific treatments that are derived from it.

An emergent English as a second or foreign language industry has also triggered the development of the courses as well as the materials. With more and more teachers are prepared to be specialising in TOEFL ITP preparation. Recently, it is found that in many urban areas across the English-learning world, there are many TOEFL coaching schools are recruiting university teachers for weekend instruction, and more and more secondary schools and colleges are offering special TOEFL preparation courses.

\section{CONCLUSION}

From the explanation above, it can be concluded that any academic institutions, scholarships providers, as well as any organizations that use TOEFL ITP as one requirement to accept or reject the test takers or applicants must reconsider some facts. Firstly, this kind of TOEFL is practical to be conducted as long as the standardized rooms and facilities should be followed. Still, there should be reconsidered about the number of test takers and their fairness to get the same treatment and facilities.

Secondly, it is true that the TOEFL ITP is a lot more affordable. However, some skills are not tested here. In this TOEFL ITP, participants who have more ability in the untested skills will get unfair result. Therefore, for the institutions that still prefer to use the TOEFL ITP test for any considerations, are advised to conduct additional test, particularly in Speaking and Writing ability.

Additionally, it is understood that the cost influences the number of test takers and applicants. However it must be understood that this test is not the genuine TOEFL since the test are taken from the previous tested TOEFL items. From this fact, it can be seen the validity is still questioned. For the organization who use this test, it is also a good idea to keep use the record of this test for preliminary information. After being short listed, the organization should conduct their test which is more reliable and valid or having a more genuine test such as TOEFL iBT or TOEFL PBT.

All in all, the TOEFL ITP is good as a pre-test before the test takers to take the actual TOEFL. Also it is good to be use to estimate the English ability in mass number of test takers.

\section{ACKNOWLEDGEMENT}

The researchers would like to deliver his acknowledgement to Universitas Muhammadiyah Sidoarjo for all facilities given during the progress of finishing this project. The researchers would like also to thank based on some revision and suggestion given by colleagues and reviewers as well as the participants in the International Conference on Intellectuals' Global Responsibility (ICIGR) 2017.

\section{REFERENCES}

[1] Duc Huu Pham and Tu Ngoc Nguyen, (2016) "Assessment Model for Language Learners' Writing Practice (in Preparing for TOEFL iBT) Based on Comparing Structure, Vocabulary, and Identifying Discrepant Essays" International Journal of Advanced Computer Science and Applications(ijacsa), http://dx.doi.org/10.14569/IJACSA.2016.070523

[2] Farnsworth, T.L., (2013). An Investigation Into the Validity of the TOEFL iBT Speaking Test for International Teaching Assistant Certification. Language Assessment Quarterly. Volume 10, 2013 - Issue 3, https://doi.org/10.1080/15434303.2013.769548

[3] http://www.ets.org/,retrieved August 30, 2016.

[4] Kerans, M. E., E. Cid-Aranda, et al. (2011). A Test of Specialized English Reading comprehension for Spanish- and Catalanspeaking undergraduates in physical therapy: validation and variables relevant to successful performance, Universitat Internacional de Cataluny.

[5] Krnenwetter, E. (2005). TOEFL: The Next Generation. International Educator 14(5): 18. 
[6] Perez-Amurao, A. (2011). The Types and Nature of Questions visà-vis Students; TestTaking Skills as Significant Indicators of Second Language Examinees' Performance on the TOEFL-ITP Reading Comprehension Sub-Test. The International Journal of Research and Review 6(2): 39-56.

[7] Roemer, A. (2002). A more valid alternative to TOEFL?. ProQuest Central 77(4): 13.
[8] Templer, B. (2004). High-Stakes Testing at High Fees: Notes and Queries on the International English Proficiency Assessment Market. Journal for Critical Education Policy Studies 2(1).

[9] Wainer, H. and R. Lukhele (1997). How Reliable are TOEFL Scores? Educational and Psychological Measurement 57(5): 741. 